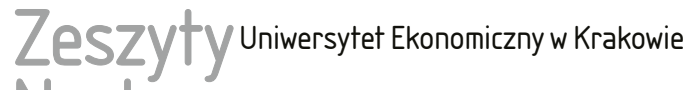 Naukowe
}

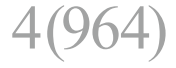

ISSN 1898-6447

Zesz. Nauk. UEK, 2017; 4 (964): 153-174 DOI: 10.15678/ZNUEK.2017.0964.0409

Grażyna Bartkowiak

Agnieszka Krugiełka

\section{Postawy Polaków z wyższym wykształceniem wobec imigrantów w zakresie współpracy zawodowej}

\section{Streszczenie}

Przedmiotem rozważań w artykule są postawy Polaków z wyższym wykształceniem wobec imigrantów. W części teoretycznej analizowane są postawy deklarowane i rzeczywiste. W szczególności rozpatrywane są postawy wobec imigrantów wybranych nacji, a także poziom ich adaptacji do kultury i obyczajowości kraju goszczącego. W części empirycznej zaprezentowano wyniki badań.

Celem artykułu jest odpowiedź na pytania: jak kształtują się postawy wykształconych Polaków wobec imigrantów i współpracy z nimi na forum zawodowym oraz czy narodowość/kraj pochodzenia ma wpływ na modalność postaw.

$\mathrm{W}$ badaniach przeprowadzanych za pomocą specjalnie opracowanego kwestionariusza oraz wywiadów pogłębionych uczestniczyło 76 osób. Wykazano w nich zróżnicowanie postaw wobec emigrantów w zakresie zastosowanych kryteriów oceny.

Słowa kluczowe: postawy wobec imigrantów, kraj pochodzenia, współpraca zawodowa, przedstawiciele innych kultur.

Klasyfikacja JEL: J62.

Grażyna Bartkowiak, Akademia Marynarki Wojennej, Wydział Nauk Humanistycznych i Społecznych, Instytut Studiów Edukacyjnych, ul. Śmidowicza 69, 81-127 Gdynia, e-mail: grazyna. bartkowiak@op.pl

Agnieszka Krugiełka, Politechnika Poznańska, Wydział Inżynierii Zarządzania, Katedra Zarządzania Produkcją i Logistyki, ul. Strzelecka 11, 60-965 Poznań, e-mail: agnieszka.krugielka@put. poznan.pl 


\section{Wprowadzenie}

Na podstawie danych z 2016 r. można stwierdzić, że Polska jest w Unii Europejskiej krajem stosunkowo jednorodnym pod względem narodowości. Zamieszkuje w niej ok. 190 tys. przedstawicieli innych nacji, z czego 16 tys. stanowią imigranci ${ }^{1}$. Dzieci imigrantów stanowią $0,6 \%$ populacji dzieci.

Duża mobilność kapitału będąca efektem liberalizacji prowadzi do nierównego podziału zasobów. Rynki pogłębiają różnice między biedą a ubóstwem, a niekończące się poszukiwanie zysku pozostaje w konflikcie z wartościami społecznymi, bezpośrednio zaś może szkodzić środowisku [Soros 2002]. Istnieją też konflikty polityczne i uwarunkowania gospodarcze, które powodują migracje ludności [Cabańska 2015, s. 89-90; Koryś i Okólski 2004, s. 25].

Jak wynika z aktualnych danych [Stefaniak i Witkowska 2015, s. 126], nasz kraj nie wydaje się uchodźcom szczególnie atrakcyjny jako docelowe miejsce imigracji.

Wybór osób z wyższym wykształceniem do badań był podyktowany przeświadczeniem o znaczącej roli społecznej osób posiadających wyższy niż przeciętny poziom kwalifikacji. Jednocześnie wybrano osoby młode, będące przedstawicielami pokolenia Y. Istnieją przesłanki, aby oczekiwać, że osoby te w przyszłości staną się decydentami, kreatorami postaw, wzorem do naśladowania dla przyszłych pokoleń [Wzory i autorytety... 2009].

Celem opracowania jest uzyskanie odpowiedzi na następujące pytania:

1) jak kształtują się postawy wykształconych Polaków wobec imigrantów i współpracy z nimi na forum zawodowym?

2) czy narodowość/ kraj pochodzenia ma wpływ na modalność postaw?

\section{Postawy - aspekty terminologiczne}

W większości opracowań z zakresu psychologii społecznej postawa oznacza ocenę obiektu postawy w aspekcie poznawczym, afektywnym i behawioralnym (np. [Fiske i in. 2002, Psychologia konsumenta... 2014, s. 331]).

Komponent poznawczy odnosi się do psychologicznej organizacji percepcyjno-intelektualnego aspektu ogólnej oceny obiektu (np. wiedza o obiekcie postawy). Komponent afektywny obejmuje poziom wrażliwości emocjonalnej, wywołujący działanie o charakterze propulsywnym (stanowiącym o atrakcyjności obiektu

\footnotetext{
${ }^{1} \mathrm{~W}$ opracowaniu pojęcie imigrantów odnosi się do osób pochodzących z innych krajów lub/i odmiennych kultur, które przybyły do kraju goszczącego w okresie ostatnich kilkunastu lat lub są przedstawicielami drugiego, trzeciego pokolenia osób, które przybyły do kraju goszczącego wcześniej.
} 
postawy) bądź repulsywnym (prowadzącym do unikania) wobec obiektu postawy. Komponent behawioralny stanowi o konkretnych, obserwowalnych aktach zachowania wobec obiektu postawy, podejmowanych w bezpośrednich relacjach z tymże obiektem [Ron 2007, s. 657].

Obserwowalne akty zachowania mogą ulegać zmianie, lecz zazwyczaj są pochodnymi komponentu poznawczego i emocjonalnego [Rosencranz i McNewin 1969, Aiken 1978].

Postawy charakteryzuje kierunek (np. wrogość lub chęć współpracy) oraz natężenie (mogą być silne lub słabe).

Większość badań dotyczących poznawczego komponentu postaw została przeprowadzona w ramach podejścia socjologicznego i psychologicznego (por. [Heckhausen, Dixon i Baltes 1989]). Wskazują one przede wszystkim na przekonania o charakterze stereotypów i uprzedzeń, które modyfikują procesy poznawcze. W podejściu socjologicznym, skoncentrowanym na ujmowaniu przekonań jako efektu procesu socjalizacji, ,wzmacnianych przez funkcjonowanie instytucji społecznych i zróżnicowanych ich struktur", dominuje społeczny, zewnętrzny charakter postrzegania.

Podejście psychologiczne koncentruje się na psychologicznych mechanizmach budowania takich przekonań i na tym, jaki przybierają one kształt w zachowaniu człowieka na poszczególnych etapach życia. W wielu badaniach starano się uwzględniać obie perspektywy.

Struktury poznawcze tworzą reprezentację poznawczą, a także schematy poznawcze jako wewnętrzne systemy informacji. Drugim źródłem wiedzy jest środowisko zewnętrzne, a więc rodzina, szkoła, rówieśnicy, zakład pracy, instytucje kulturalne czy media - środki masowego przekazu.

Postawy w zależności od tego, który komponent decyduje o ich modalności, można podzielić na deklarowane i rzeczywiste [Bartkowiak 1988, s. 6-7]. Postawy deklarowane, oparte na komponencie poznawczym, wyrażane są publicznie, w sytuacji ekspozycji społecznej, często cechuje je polityczna poprawność i racjonalna argumentacja. W przeciwieństwie do nich postawy rzeczywiste zawierają osobiste ustosunkowanie się do obiektu, odwołują się do komponentu emocjonalno-motywacyjnego i behawioralnego. Mogą wykazywać zgodność z postawami deklarowanymi, co wskazuje na ich spójność, ale mogą też być w stosunku do nich całkowicie rozbieżne. Postawy rzeczywiste decydują o konkretnych aktach zachowań i - jak można przypuszczać - to od nich zależy faktyczna wola inicjowania współpracy z przedstawicielami innych kultur, a ich badanie wymaga zastosowania bardziej skomplikowanych niż kwestionariuszowe technik badawczych (np. projekcyjnych). Postawy deklarowane można traktować jako swoiste zobowiązanie podmiotu, wstępny etap na drodze do budowania relacji z obiektem postaw. 


\section{Postawy wobec przedstawicieli innych kultur}

Postawy wobec przedstawicieli innych kultur były przedmiotem badań prowadzonych przez wielu autorów. Przykładowo model wrażliwości kulturowej M.J. Benneta (zob. rys. 1) opisuje behawioralny aspekt postaw wyzwalający określone zachowania w sytuacji różnorodności kulturowej, stanowiące kontinuum kulturowej świadomości, rozumienia i dostosowania od etnocentryzmu do etnorelatywizmu [Bennet 1993, s. 21-71].

\begin{tabular}{|c|c|}
\hline Etnocentryzm & Etnorelatywizm \\
\hline Postawa obronna & Akceptacja \\
\hline Minimalizacja & Adaptacja \\
\hline Odrzucenie i izolacja & Integracja \\
\hline Wrogość & \\
\hline
\end{tabular}

Rys. 1. Tolerancja wobec odmienności kulturowej

Źródło: [Bennet 1993, s. 22].

Stadium etnocentryzmu charakteryzuje się odrzucaniem różnic kulturowych, wizją świata, w której kultura podmiotu dokonującego oceny jest osią centralną i prowadzi do dezakceptacji wszelkich różnic kulturowych. Sprowadza się do izolacji (kiedy podmiot nie chce nawiązywać kontaktów z przedstawicielami innych kultur) oraz do separacji (kiedy podmiot w sposób świadomy separuje się od doświadczania odmienności kulturowej, aby utrzymać swój obraz świata). Stadium obrony przed odmiennością kulturową sprowadza się do dywersyfikacji świata na „nasz świat” i ,ich świat”. W ramach tego stadium dochodzi do oczerniania innych kultur i ich przedstawicieli, wywyższania przedstawicieli własnej kultury. Minimalizowanie różnic kulturowych sprowadza się do uznania uniwersalnych fizycznych charakterystyk wszystkich ludzi, wyznaczających zachowanie, niezależnie od różnic kulturowych, oraz transcendentalnego uniwersalizmu odwołującego się do wspólnych wartości. Uniwersalizacja wartości odnosi się jednak do własnej wizji świata uznawanej przez podmiot. Na tym poziomie różnice kulturowe bywają trywializowane lub traktowane jako „romantyczne”.

Ostatnie stadium nosi miano etnorelatywizmu. W ramach tego stadium odmienność kulturowa bywa rozpatrywana relatywnie, a poszczególne zachowania są zrozumiałe jedynie w odniesieniu do kontekstu kulturowego. Etnorelatywizm sprowadza się do akceptacji rozbieżności kulturowych i traktowania własnej kultury jako jednej z wielu możliwości postrzegania świata, co oznacza posza- 
nowanie dla odmiennych wzorców zachowań oraz poszanowanie odmiennych wartości jako przejawów odmiennych przekonań funkcjonujących w określonym kontekście kulturowym.

W badaniach postaw wobec przedstawicieli innych nacji i innego wyznania autorstwa A. Majdy, J. Zalewskiej-Puchały i E. Barczyk [2013], przeprowadzonych z wykorzystaniem skali Bogardusa (skala dystansu społecznego) w grupie 100 studentów pielęgniarstwa, stwierdzono, że $77 \%$ badanych prezentuje negatywną postawę wobec Romów, 69\% wobec muzułmanów, a 55\% wobec Żydów.

O negatywnych postawach Polaków wobec mniejszości narodowych pisali także inni autorzy (np. [Nowicka 2011, Stefaniak, Bilewicz i Winiewski 2015]. Nawiązując do konkretnych badań, potwierdzają oni istnienie w Polsce uprzedzeń i stereotypów wobec mniejszości narodowych i religijnych, w szczególności Arabów i muzułmanów. Choć tych ostatnich w pierwszej dekadzie XXI w. naliczono nie więcej niż 10-20 tys. [Marek i Skowron-Nalborczyk 2005], należą oni do najmniej akceptowanych grup mniejszościowych w naszym kraju. Antypatia wobec nich, zdaniem Z. Strabac i O. Listhaug [2008], przybierać może postać islamofobii i może być efektem specyficznego lęku międzygrupowego, który najczęściej sprowadza się do dyskomfortu odczuwanego na myśl o kontakcie z grupą obcą [Stephan i Stephan 1985, Zomeren, Fisher i Spears 2007].

Optymistycznym wnioskiem płynącym z badań jest to, że interpersonalne kontakty społeczne spowodowane np. wyjazdem i wspólnym studiowaniem w ramach program Erasmus zmieniają to nastawienie. Analiza statystyczna poziomu dystansu społecznego, jaki odczuwali polscy studenci wobec wyznawców islamu po pobycie na wyjeździe zagranicznym wykazała, że dystans ten zmalał w sposób statystycznie istotny (badanie powtórzone po pół roku) w stosunku do stanu wyjściowego (poziom dystansu społecznego przed wyjazdem: $M=2,21$, $S D=0,73$, po powrocie $M=1,17, S D=0,64)$.

\section{Badania dotyczące możliwości adaptacji imigrantów}

W literaturze przedmiotu problematyka dotycząca zdolności adaptacyjnych imigrantów nie jest obszernie omawiana. Dostrzec można jednak, że w ostatnich dwóch dekadach powstawało więcej opracowań na ten temat. Opracowania te dotyczyły różnych aspektów zachowania imigrantów, m.in.:

- wzorców funkcjonowania rodziny i uczestnictwa w edukacji w kontekście zróżnicowania pokoleń i pochodzenia rodziców,

- sytuacji na rynku pracy,

- stosunku do uregulowań prawnych,

- korzyści z imigracji dla kraju goszczącego. 
Wzorce funkcjonowania rodziny

Zagadnienia związane $\mathrm{z}$ funkcjonowaniem rodziny zostały w literaturze przedmiotu omówione najszerzej. Liczni autorzy podkreślają konieczność zajęcia się zagadnieniem funkcjonowania młodych imigrantów, którzy stanowią coraz większy odsetek populacji w wieku wczesnej dorosłości [Huschek, Liefbroer i Valk 2010, Zorlu i Mulder 2011, Migrants in Europe... 2011].

M. Windzio [2011] wskazał na powiązanie wzorców rodzinnych z możliwością uzyskiwania wyższego wykształcenia przez młodych absolwentów szkół średnich. W opinii tego autora wczesne opuszczanie przez dzieci imigrantów domu rodzinnego jest czynnikiem utrudniającym uzyskanie wyższego wykształcenia. Zdaniem innych autorów, powielanie wzorców wczesnego macierzyństwa przez młode kobiety opóźnia ich wejście na rynek pracy, a podjęcie pierwszej pracy wyznacza karierę zawodową. Wczesne macierzyństwo ogranicza też ich niezależność [Garssen i Nicolaas 2008, Hobcraft i Kiernan 2001].

Większość autorów podkreśla mniejszą zdolność adaptacyjną przedstawicieli kultur Azji Wschodniej i Afryki Północnej (np. Turcja, Maroko), kultywowanie tradycji, przestrzeganie wymagań i zaleceń religijnych, zależność od rodziny itp. [Hartgers i Besjes 2014, Heath, Rothon i Kipli 2008, Lesthaeghe 2010]. Zależność ta dotyczy szczególnie młodych kobiet wyznających islam, które podlegają dużej społecznej presji ze strony zarówno swojej rodziny, jak i otoczenia [Kleinepier i Valk 2015, s. 674-695]. Aktualne badania przeprowadzone w Norwegii wskazują jednak na osłabianie się wpływów tradycji w drugim pokoleniu imigrantów, jeśli młodzi ludzie byli wychowywani przez rodziców, z których jedno pochodziło z kraju goszczącego. Inaczej jest, gdy oboje rodziców ma pozaeuropejskie pochodzenie, a ich dzieci urodziły się w kraju, do którego emigrowali. Osłabianie tendencji płynących z tradycji obejmuje najczęściej samodzielne zamieszkanie, związek partnerski, posiadanie dzieci ze związku pozamałżeńskiego, podejmowanie nauki na studiach wyższych, a następnie pracy zawodowej i bycie singlem.

Wtapianie się w kulturę kraju goszczącego jest procesem, którego efekty należy obserwować przez longitudinalne badania uwzględniające styl życia w perspektywie kilku pokoleń.

\section{Funkcjonowanie na rynku pracy}

Liczni autorzy podkreślają, że niezbyt duża adaptacja imigrantów do kultury i obyczajowości holenderskiej jest efektem określonej, niezbyt wspierającej polityki państwa wobec imigrantów, która sprawia, że napotykają oni trudności na rynku pracy, a beneficja socjalne nie spełniają ich oczekiwań (np. [Immigrant Integration... 2000]).

Zdaniem niektórych badaczy [Hartgers i Besjes 2014, Heath, Rothon i Kipli 2008] pozycja społeczna rodziców imigrantów aktualnie będących w okresie 
wczesnej dorosłości, która była zdeterminowana statusem społecznym rodziny generacyjnej i niedostosowaniem posiadanych kompetencji do zapotrzebowania na rynku, czasem niskim poziomem wykształcenia, do chwili obecnej determinuje sytuację zawodową i życiową ich dzieci, w taki sposób, że nadal mają oni mniejsze szanse życiowe i zawodowe niż ich rówieśnicy z kraju, w którym mieszkają [Chiswick, Cohen i Zach 1997, s. 298-291].

\section{Stosunek do prawa}

Zdaniem niektórych badaczy zarówno proces adaptacji do kultury i obyczajowości goszczącego kraju, jak i postawy wobec imigrantów są uwarunkowane dochowaniem przez imigrantów prawa w goszczącym kraju [Hein i Beger 2001, s. 422]. Stosunek do przepisów prawnych jest kryterium pozwalającym na wyodrębnienie legalnych i nielegalnych imigrantów [Chiswick, Cohen i Zach 1997, s. 290-291], a jednocześnie czynnikiem różnicującym postawy wobec tej grupy osób. Problem ten wydaje się szczególnie trudny, gdy dotyczy sytuacji na rynku pracy. W literaturze można znaleźć przykłady złego traktowania nielegalnych imigrantów. J. Smolin [2011], podejmując temat nielegalnej imigracji Marokańczyków do Europy i Stanów Zjednoczonych, podaje przykłady bardzo rygorystycznego traktowania przybyszów, łącznie ze skazywaniem ich na pobyt w więzieniu.

Podsumowując, postawy wobec nielegalnych imigrantów, niezależnie od ich sytuacji życiowej, można uznać za negatywne.

\section{Korzyści z imigracji dla kraju goszczqcego}

Korzystnym rozwiązaniem z punktu widzenia pozytywnej, stymulującej rozwój gospodarczy roli imigrantów (na przykładzie Stanów Zjednoczonych) jest samozatrudnienie i tworzenie przez nich firm rodzinnych. J.M. Sanders i V. Nee [1996, s. 232-233] twierdzą, że stanowi ono antidotum na niezbyt wysoko oceniany poziom kapitału intelektualnego i profesjonalizmu, który zostaje skompensowany przez dobrze rozwijający się kapitał społeczny. W ten sposób wzajemne zaufanie członków rodzinnych firm i lokalnych społeczności mniejszościowych zastępuje deficyt kompetencji, który jest wyrównywany przez efekt synergii, zróżnicowania zespołów pracowniczych. Z kolei małe firmy, często o charakterze usługowym, przez zaspokajanie potrzeb klientów i konsumentów skutecznie wspierają amerykańską gospodarkę.

$\mathrm{Z}$ innym rodzajem wsparcia gospodarki, z przepływem wiedzy i kapitału społecznego mamy do czynienia w przypadku tworzenia lokalnych społeczności imigranckich. Przykładem są imigranci włoscy w Rumunii [Dobrescu 2015, s. 414]. Społeczności te mają tradycje sięgające XII w., a dobrosąsiedzka współpraca wspierana formami organizacyjnymi jest wzorem godnym naśladowania. Szczególne osiągnięcia dotyczą troski o rozwój agrokultury, a w okresie ostatnich trzech dekad także działalności wspierającej lokalny i międzynarodowy handel. 
Pogląd ten różni się jednak od wniosków z badań, które przeprowadzili B.R. Chiswick, Y. Cohen i T. Zach [1997, s. 298-291 i 301]. Rozpatrując sytuację imigrantów w Stanach Zjednoczonych, podkreślali, że nie ma wystarczająco przekonujących powodów, aby wyraźnie różnicować status na rynku pracy imigrantów w porównaniu z rodowitymi obywatelami Stanów Zjednoczonych, choć w zakresie poziomu bezrobocia mierzonego wśród Europejczyków, Kanadyjczyków i Azjatów są znaczące różnice na korzyść tych ostatnich. Sytuacja ta wynika z wyższego poziomu edukacji i większej determinacji w zdobywaniu i utrzymywaniu pracy wśród pochodzących z tego kontynentu.

\section{Organizacja badań własnych}

Badania przeprowadzono za pomocą specjalnie opracowanego kwestionariusza do badania postaw wobec zatrudniania imigrantów, złożonego z 10 pytań, których sformułowanie umożliwiły badania pilotażowe. Osoby w nich uczestniczące (46 badanych) podawały propozycje twierdzeń, które klasyfikowano jako odpowiedzi na poszczególne wcześniej sformułowane pytania. Jeśli określone pozycje, zarówno pytania, jak i odpowiedzi, zostały wskazane przez co najmniej 51\% osób uczestniczących w badaniach pilotażowych, pytanie i twierdzenia zawierające odpowiedzi włączano do ostatecznej wersji kwestionariusza (miało to miejsce w przeważającej liczbie przypadków). Współczynnik rzetelności $\alpha$ Cronbacha dla całego kwestionariusza wyniósł 0,76 .

$\mathrm{W}$ analizowanej procedurze badawczej przyjęto założenie dotyczące dywersyfikacji postaw i wyodrębniono postawy deklarowane i rzeczywiste. Większość pytań występujących w kwestionariuszu (z wyjątkiem pytań 6 i 7) odnosiła się do postaw deklarowanych. Pytania przeznaczone do badania postaw rzeczywistych dotyczyły form akceptacji współpracy na forum zawodowym oraz emocji towarzyszących kontaktom z osobami z innych krajów i/lub reprezentujących odmiennną kulturę. Wypowiedzi badanych odnoszące się do postaw rzeczywistych klasyfikowano, korzystając z metody sędziów kompetentnych (dwóch praktyków i dwóch teoretyków, specjalistów w zakresie psychologii zarządzania). Zmiennymi były modalność postaw oraz ich zróżnicowanie.

W badaniach właściwych uczestniczyło 76 osób posiadających wykształcenie wyższe (techniczne, ekonomiczne i humanistyczne), słuchaczy studiów podyplomowych, przedstawicieli pokolenia Y (osoby urodzone w latach 1980-2000). Średnia wieku wynosiła 32,2 roku, a proporcja płci była zrównoważona z ok. 10-procentową przewagą kobiet. 


\section{Postawy wobec imigrantów w świetle wyników badań}

Na podstawie analizy kwestionariuszy stwierdzono, że postawy wobec imigrantów prezentowane przez badanych są zróżnicowane. Na postawy te ma z pewnością wpływ częstotliwość kontaktów z osobami z innych krajów i/lub reprezentujących inną kulturę (zob. rys. 2).

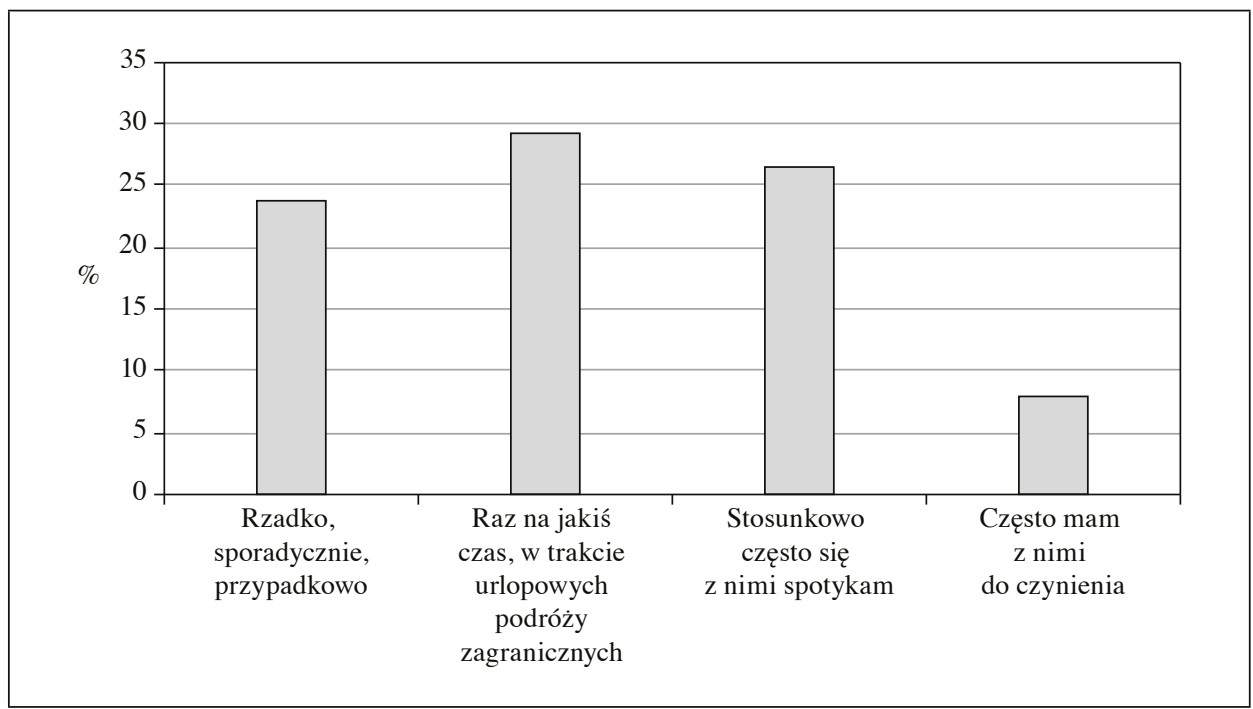

Rys. 2. Częstotliwość kontaktów z osobami pochodzącymi z innych krajów i/lub reprezentującymi inną kulturę

Źródło: opracowanie własne.

Jak wynika z badań, ponad 50\% respondentów nie posiada wielu doświadczeń związanych z bezpośrednimi kontaktami z osobami z innych krajów i/lub reprezentującymi inną kulturę. $Z$ tego względu ich opinie wydają się w większym stopniu oparte na stereotypach i uprzedzeniach. Ponadto mogą one być obciążone opiniami pochodzącymi z innych źródeł, np. od znajomych lub z mediów.

Osoby badane, jak wynika z przedstawionych danych, najczęściej kontaktowały się z mieszkańcami Europy Zachodniej, a następnie z osobami pochodzącymi z Europy Południowej i krajów byłego Związku Radzieckiego: Ukrainy, Białorusi, Rosji, Gruzji i Kazachstanu (rys. 3).

Jedynie 34\% osób bezpośrednio współpracowało z obcokrajowcami, z czego ok. $24 \%$ pochodziło z Europy Zachodniej. Czynnik ten wydaje się w znacznym stopniu kształtować postawy wobec imigrantów (rys. 4). 


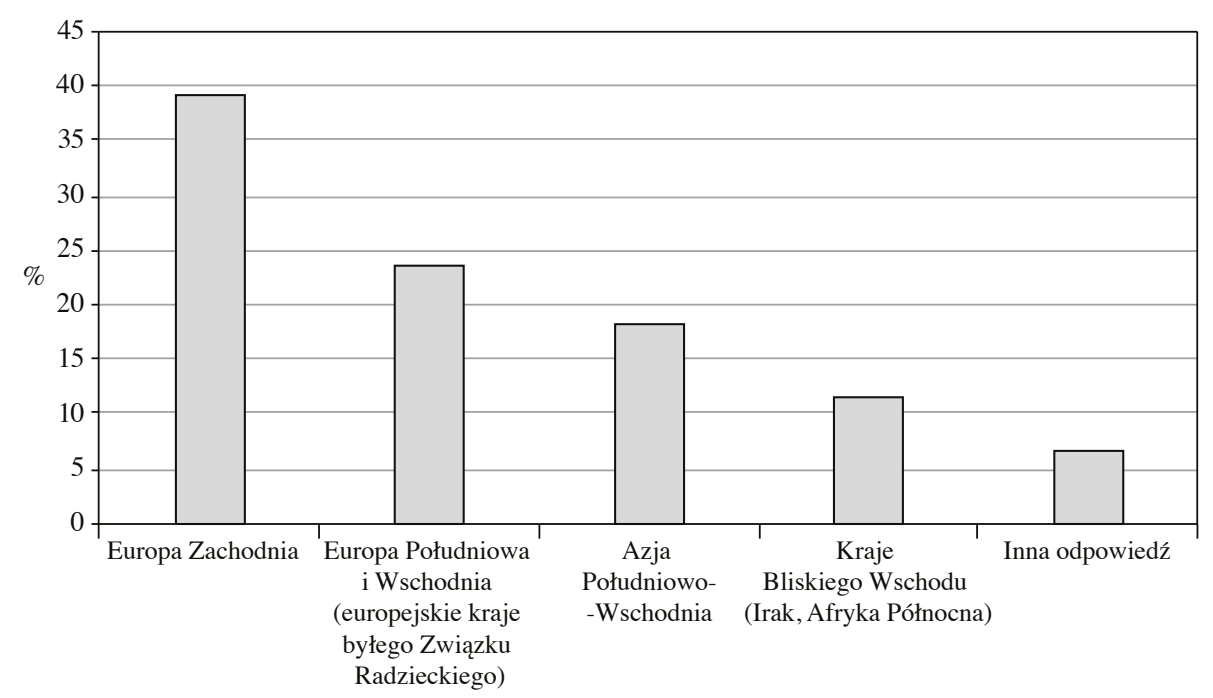

Rys. 3. Pochodzenie imigrantów

Źródło: opracowanie własne.

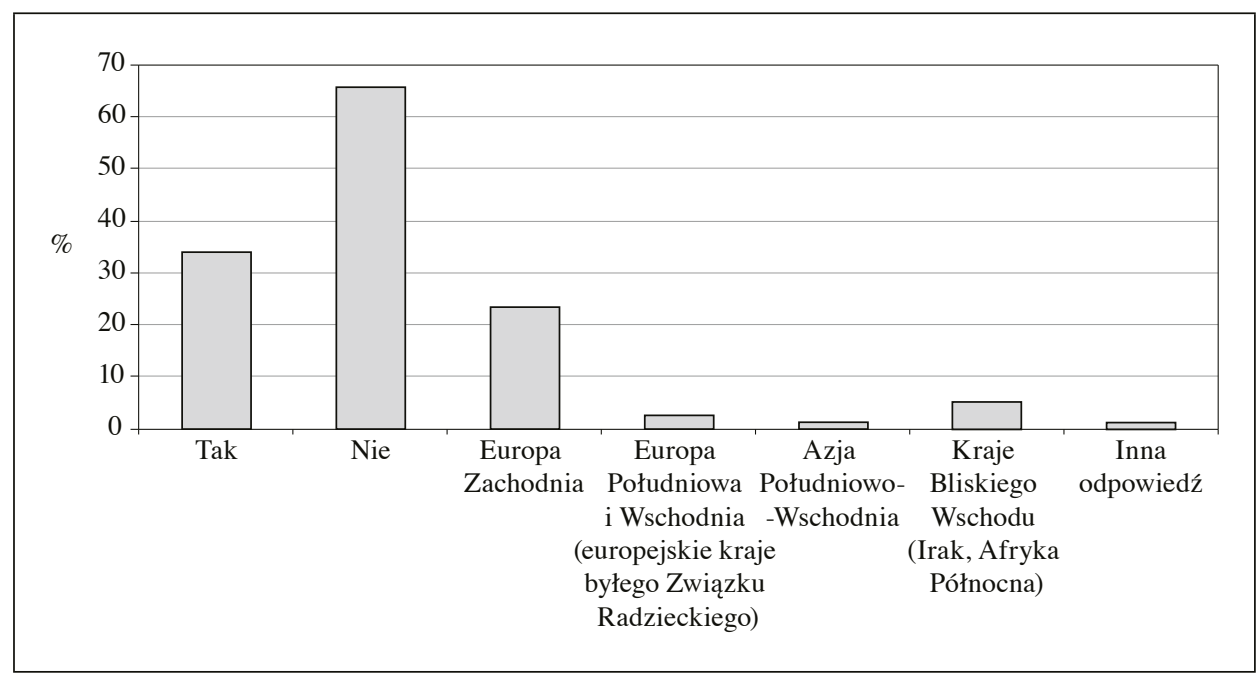

Rys. 4. Posiadanie doświadczeń bezpośredniej współpracy z osobami pochodzącymi z innych krajów i/lub reprezentującymi inną kulturę

Źródło: opracowanie własne. 
Na podstawie oceny sędziów kompetentnych, która pozwoliła na wyodrębnienie określonej kategorii postaw, stwierdzono, że w badanej grupie najczęściej występowały postawy umiarkowanie pozytywne i pozytywne (łącznie ponad 47\%) oraz postawy zróżnicowane (ok. 33\%). Dane napawają optymizmem i pozwalają sądzić, że dalsze relacje respondentów z obcokrajowcami będą dobre ${ }^{2}$ (rys. 5).

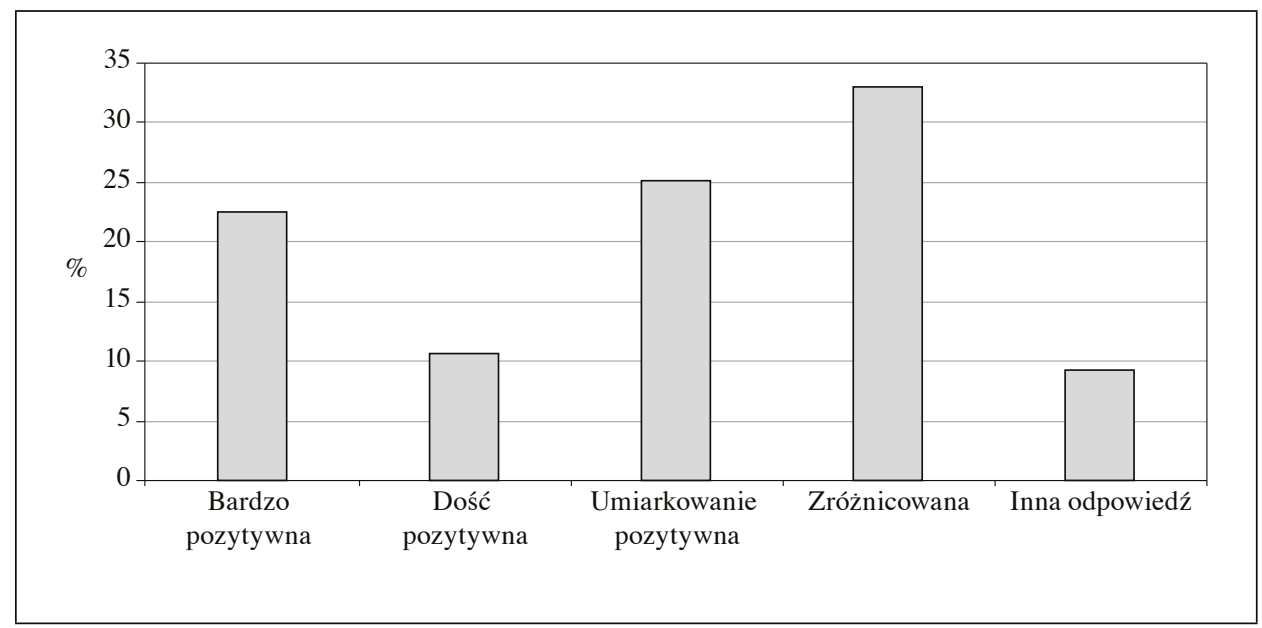

Rys. 5. Klasyfikacja postaw dotyczących kontaktów z osobami pochodzącymi z innych krajów i/lub reprezentującymi inną kulturę

Źródło: opracowanie własne.

Ocena własnych kompetencji językowych (zob. rys. 6) wypada umiarkowanie korzystnie. Większość osób badanych ocenia je jako niewystarczające (ok. 35\%). Jednocześnie ok. 28\% badanych pozytywnie ocenia własną znajomość języka obcego (zazwyczaj chodzi o znajomość języka angielskiego).

Analizując poziom akceptacji współpracy zawodowej z osobami z Europy i innego kręgu kulturowego z wykorzystaniem metody projekcyjnej, zaobserwowano istnienie statystycznie istotnej zależności między poziomem akceptacji

2 Analiza statystyczna wykazała współwystępowanie pozytywnych (bardzo pozytywnych i dość pozytywnych) deklarowanych postaw z wyższą częstotliwością kontaktów i posiadaniem pozytywnych doświadczeń współpracy zawodowej z imigrantami reprezentującymi inną kulturę. Zależność tę weryfikowano za pomocą testu niezależności chi-kwadrat Pearsona. Wartość statystyki testu chi-kwadrat wynosiła 11,132, co w konfrontacji z wartością krytyczną (chi-kwadrat $=9,487$ przy $d f=4$, na poziomie istotności równym $\alpha=0,05$ ) prowadzi do odrzucenia hipotezy o niezależności określonych postaw wobec imigrantów i oceny dotychczasowych własnych kontaktów z przedstawicielami innych krajów i/lub kultur. 


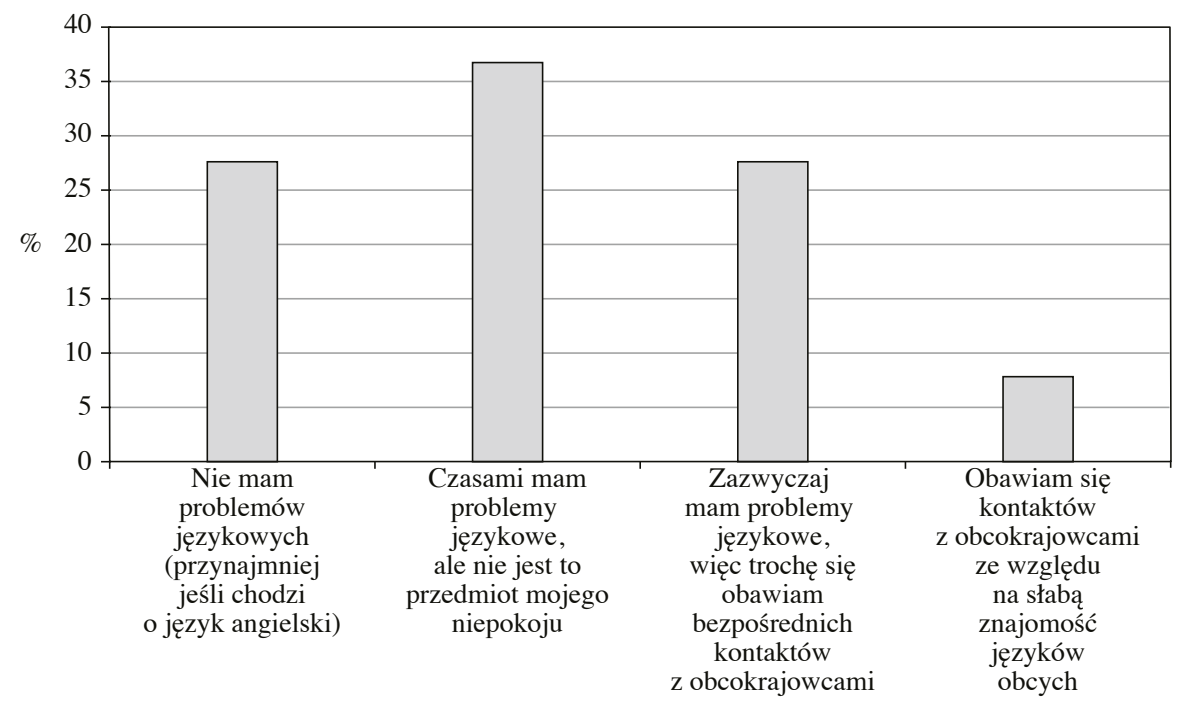

Rys. 6. Bariery językowe w kontaktach z przedstawicielami innych krajów i/lub kultur Źródło: opracowanie własne.

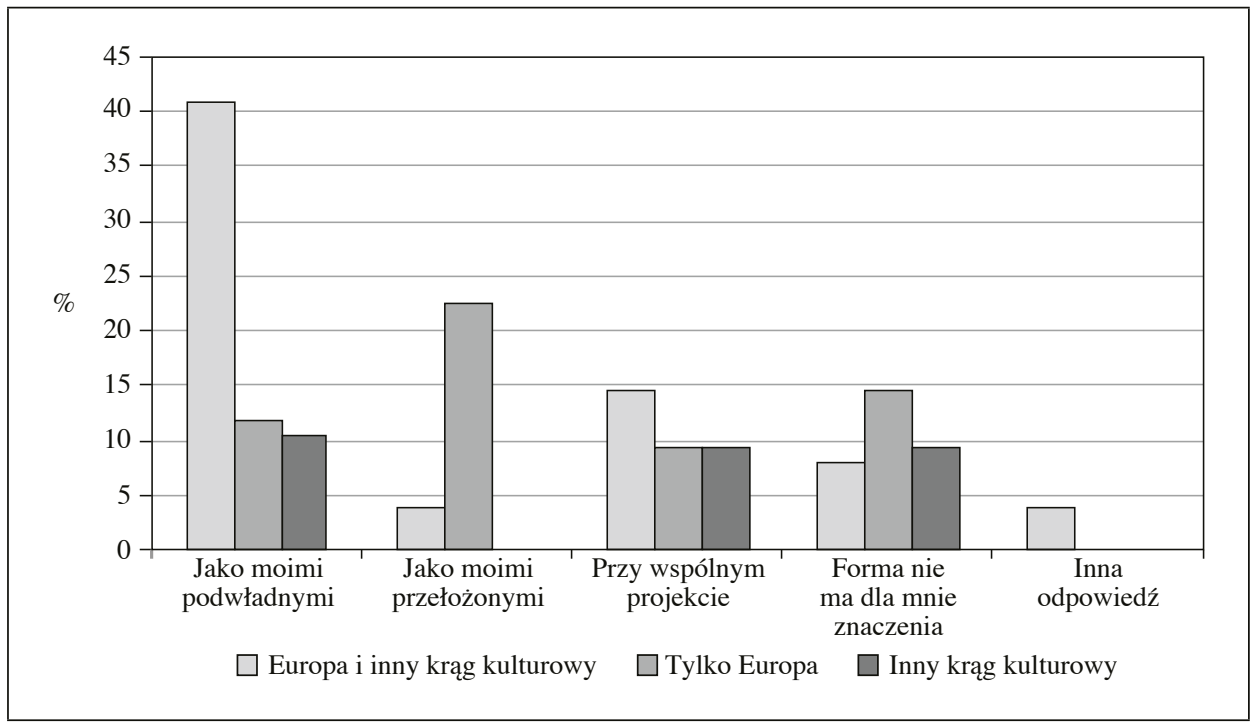

Rys. 7. Akceptacja formy współpracy zawodowej z przedstawicielami innych krajów i/lub kultur

Źródło: opracowanie własne. 
współpracy a krajem pochodzenia imigrantów ${ }^{3}$. Rozbieżności te dotyczą dwóch kategorii związanych z relacją przełożony-podwładny. Łącznie ponad $62 \%$ osób uczestniczących w badaniach mogłoby zaakceptować obcokrajowców jako swoich podwładnych, ale tylko ok. $26 \%$ badanych uznałoby zwierzchnictwo organizacyjne obcokrajowców. Na uwagę zasługuje fakt, że żadna z osób badanych nie chciałaby mieć przełożonego z innego kręgu kulturowego, tj. z krajów Azji Południowo-Wschodniej lub Afryki Północnej (rys. 7).

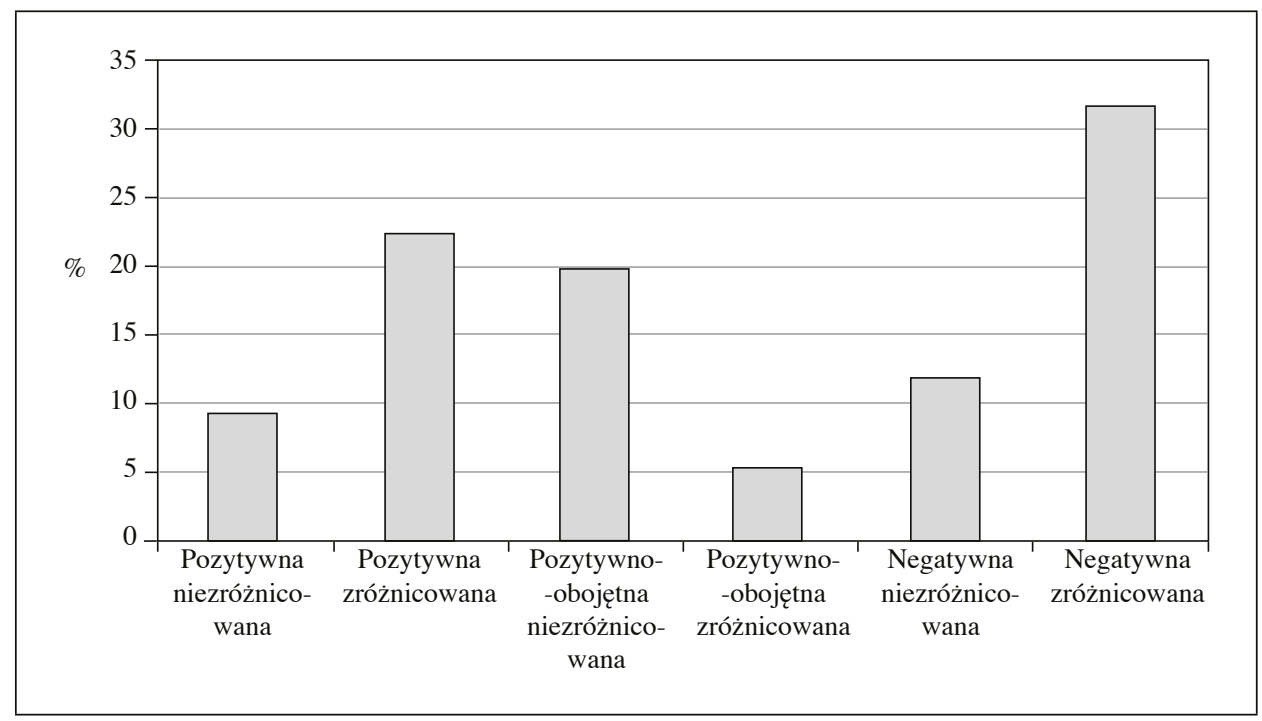

Rys. 8. Postawy wobec współpracy z imigrantami dotyczące pracy przy wspólnym projekcie (łączne ujęcie)

Źródło: opracowanie własne.

Dane odnoszące się do postaw rzeczywistych diagnozowanych w wyniku zastosowanie pytania o charakterze projekcyjnym wskazują, że osoby badane najczęściej prezentowały postawy negatywne, ale ich natężenie uzależnione było od kraju pochodzenia imigrantów. Najbardziej negatywne postawy odnosiły się do

${ }^{3}$ Za wyższy poziom współpracy przyjęto odpowiedzi ,praca przy wspólnym projekcie”, ,nie ma to dla mnie znaczenia” oraz ,,jako moimi przełożonymi”. Za niższy poziom odpowiedź ,jako moimi podwładnymi". Zależność tę weryfikowano za pomocą testu niezależności chi-kwadrat Pearsona. Wartość statystyki testu chi-kwadrat wynosiła 14,722, co w konfrontacji z wartością krytyczną (chi-kwadrat $=9,487$ przy $d f=4$, na poziomie istotności równym $\alpha=0,05$ ) prowadzi do odrzucenia hipotezy o niezależności poziomu akceptacji współpracy zawodowej z przedstawicielami innych krajów i/lub kultur od krajów ich pochodzenia. 
osób, które przybyły z Afryki Północnej i Azji Południowo-Wschodniej. Optymizmem napawa fakt, że na drugim miejscu pod względem częstotliwości występowania znalazły się pozytywne postawy zróżnicowane. Podobnie jak w przypadku postaw negatywnych były one bardziej pozytywne w stosunku do mieszkańców Europy i krajów części europejskiej byłego Związku Radzieckiego niż w stosunku do imigrantów z Afryki Północnej i Azji Południowo-Wschodniej (rys. 8).

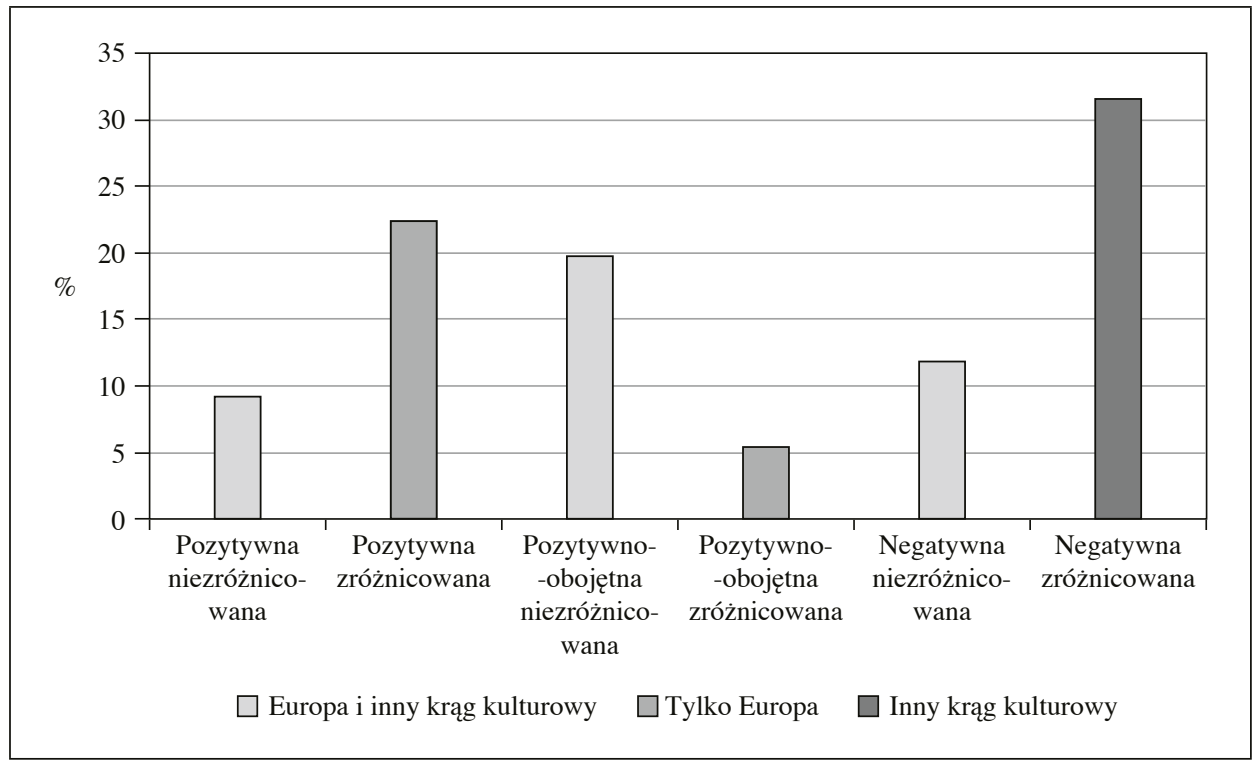

Rys. 9. Postawy wobec współpracy zawodowej z imigrantami dotyczące pracy przy wspólnym projekcie (w zależności od miejsca pochodzenia emigrantów) Źródło: opracowanie własne.

Rozważenie możliwości podjęcia współpracy przy wspólnym projekcie wykazało zróżnicowanie postaw w zależności od kraju pochodzenia imigrantów (rys. 9). Na uwagę zasługuje fakt, że ponad $22 \%$ respondentów ujawniło pozytywne postawy tylko w odniesieniu do przedstawicieli krajów Europy, a ok. 32\% postawy negatywne tylko w odniesieniu do osób z innego kręgu kulturowego (imigrantów z Afryki Północnej i Azji Południowo-Wschodniej).

Refleksja nad emocjami towarzyszącymi kontaktom z imigrantami (zob. rys. 10) pozwoliła zaobserwować następujące rodzaje odczuć: brak szczególnych emocji wobec imigrantów (ok. 36\%), ciekawość wobec imigrantów z Europy i innego kręgu kulturowego (ok. 25\%) oraz poczucie niepewności w relacjach z osobami reprezentującymi inny krąg kulturowy (ok. 20\%). 


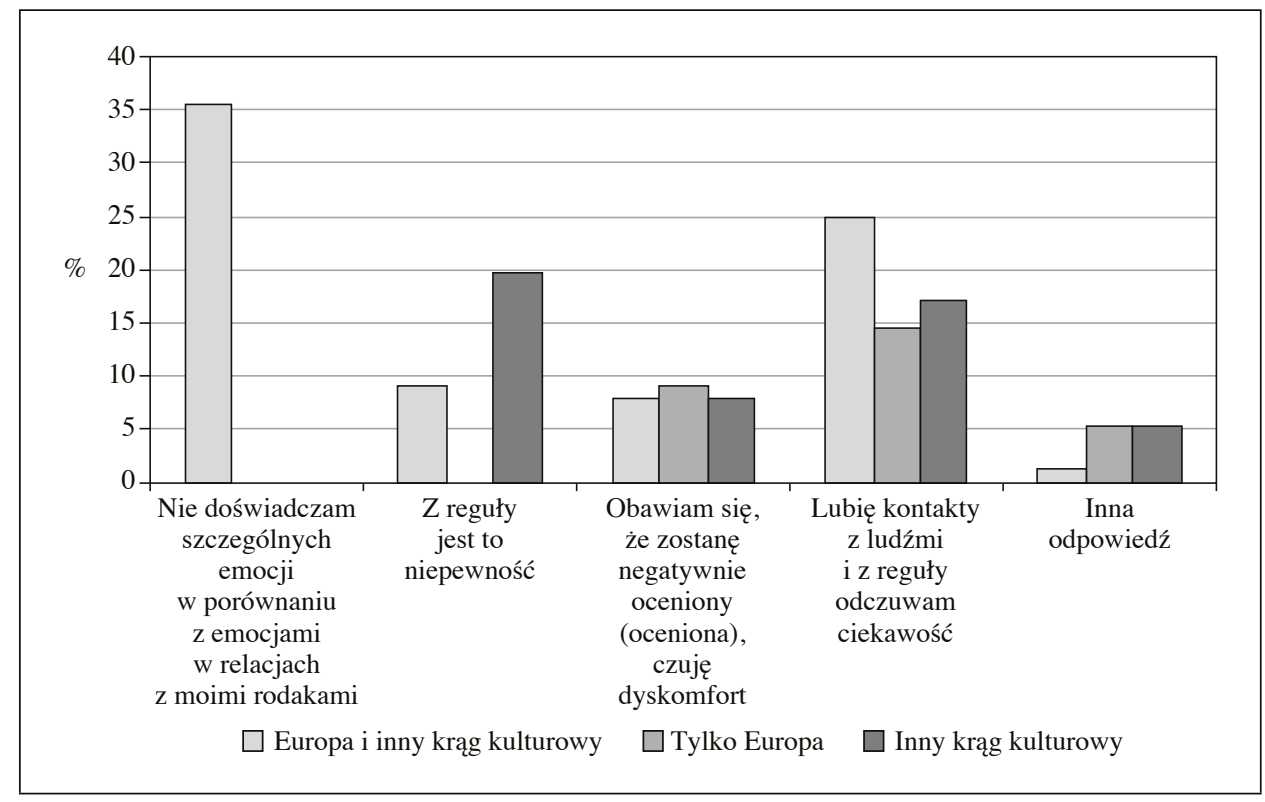

Rys. 10. Emocje towarzyszące kontaktom z przedstawicielami innych krajów i/lub kultur Źródło: opracowanie własne.

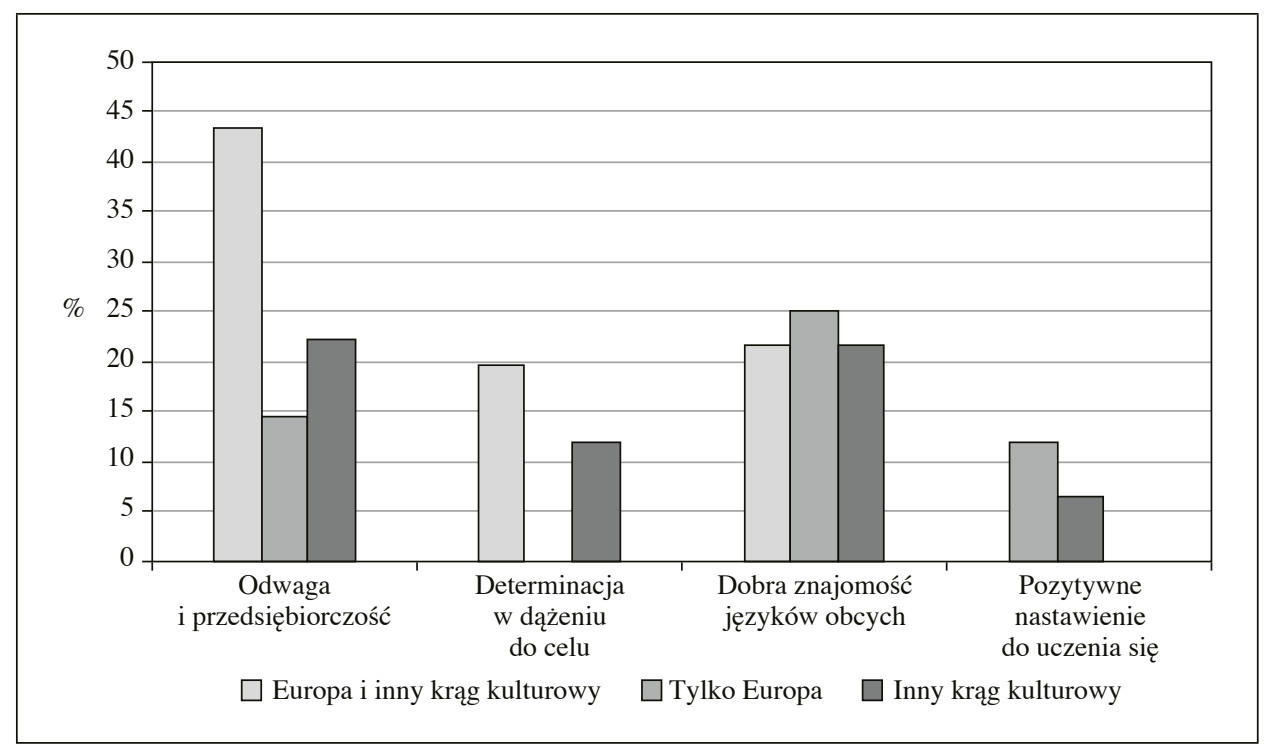

Rys. 11. Mocne strony przedstawicieli innych krajów i/lub kultur Źródło: opracowanie własne. 
Do mocnych stron wszystkich imigrantów niezależnie od kraju pochodzenia z pewnością należy zaliczyć odwagę i przedsiębiorczość (22-43\%). Cecha ta w opinii respondentów w mniejszym stopniu charakteryzuje przybyszów z Europy. Podobnie wysoko oceniono znajomość języków obcych, która w przeciwieństwie do odwagi i przedsiębiorczości w największym stopniu charakteryzuje właśnie Europejczyków (ok. 25\%). Odpowiednie dane zaprezentowano na rys. 11.

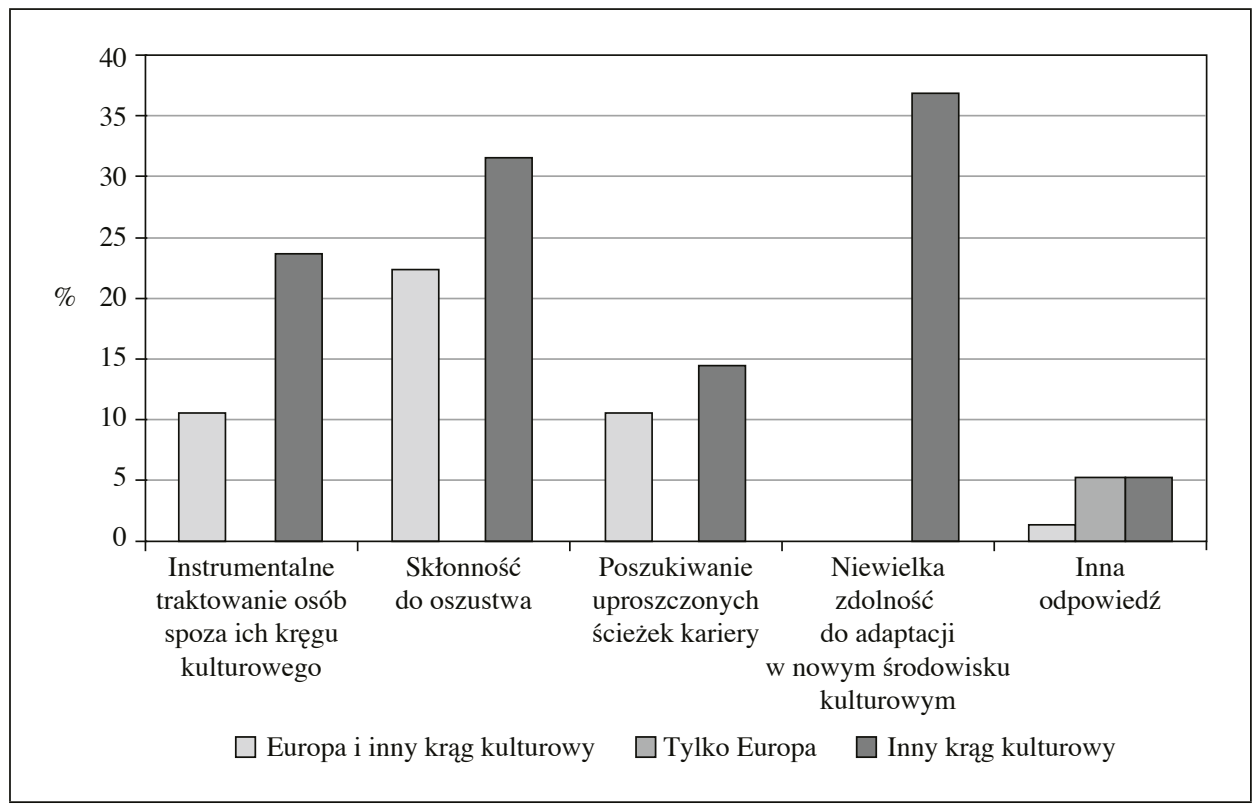

Rys. 12. Negatywne cechy przedstawicieli innych krajów i/lub kultur Źródło: opracowanie własne.

Za negatywne cechy w największym stopniu charakteryzujące imigrantów z innego kręgu kulturowego uznano niewielką zdolność do adaptacji w nowym środowisku kulturowym (ok. 37\%), skłonność do oszustwa (ok. 32\%) oraz instrumentalne traktowanie osób spoza ich kręgu kulturowego (ok. 24). Dane na ten temat zaprezentowano na rys. 12.

Wypowiadając się na temat działań zaradczych i promujących kształtowanie pozytywnych postaw dotyczących współpracy z imigrantami na forum zawodowym i szerszym forum społecznym, respondenci w pierwszej kolejności wskazali na promowanie wiedzy o odmiennych kulturach i innych krajach (ok. 41\%). Następnie zwrócili uwagę na brak konieczności podejmowania szczególnej ingerencji zewnętrznej i uznali, że kształtowanie się wzajemnych postaw imigrantów i mieszkańców kraju goszczącego to proces naturalny (ok. 37\%). Ostatnia sugestia 


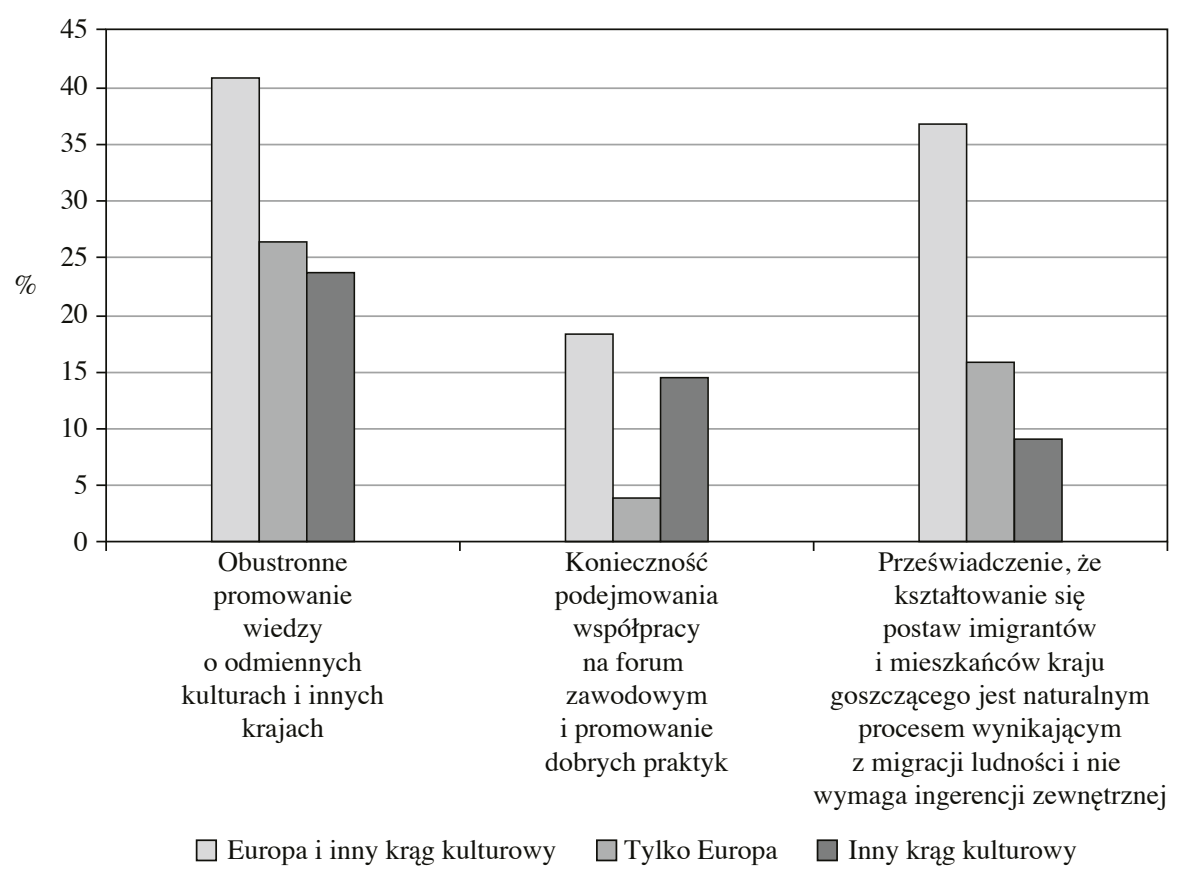

Rys. 13. Działania pozwalające ograniczyć nierzetelne oceny przedstawicieli innych krajów i/lub kultur

Źródło: opracowanie własne.

wydaje się świadczyć o dojrzałości respondentów i umiejętności szerszego spojrzenia na problem, jak również o zdolności do zachowania swoistego dystansu do problematyki kształtowania postaw wobec uchodźców. Jednocześnie ok. 43\% respondentów opowiedziało się za promowaniem większej częstotliwości wzajemnych kontaktów i dobrych praktyk, zarówno wśród dzieci i młodzieży, jak i wśród osób dorosłych, które częściej, niż to ma miejsce aktualnie, powinny podejmować współpracę na forum zawodowym (rys. 13).

\section{Podsumowanie}

W analizowanych badaniach przyjęto założenie dotyczące dywersyfikacji postaw i wyodrębniono postawy deklarowane i rzeczywiste. Pytania kwestionariusza podejmujące problem akceptacji form współpracy z imigrantami i emocji towarzyszących kontaktom z przedstawicielami innych krajów i/lub kultur posłużyły do badania postaw rzeczywistych. 
Uzyskane wyniki wskazują na zróżnicowanie deklarowanych i rzeczywistych postaw respondentów wobec imigrantów. Postawy te bywają bardzo pozytywne, ale i negatywne, w zależności od częstotliwości kontaktów, podejmowania bezpośredniej współpracy i innych rozpatrywanych czynników.

Badania postaw rzeczywistych potwierdziły zróżnicowanie w zależności od kraju pochodzenia. Znamienny wydaje się fakt, że na ogół nie są to postawy dopuszczające bliskość kontaktów i akceptację relacji podlegania służbowego osobom z odmiennego kręgu kulturowego.

Zaprezentowane dane pozwalają na wyodrębnienie ważnych czynników, które mogły mieć wpływ zarówno na kształtowanie się samych postaw wykształconych Polaków wobec imigrantów, jak i na ich zróżnicowanie. Należą do nich:

- doświadczenie we współpracy z imigrantami i częstotliwość kontaktów,

- istniejące stereotypy odnoszące się do ich charakterystyki i konkretnych zachowań,

- informacje przekazywane przez media,

- kraj pochodzenia imigrantów.

Doświadczenie we wzajemnych relacjach wydaje się w znaczącym stopniu kształtować postawy wobec imigrantów. Z drugiej strony należy mieć świadomość, że postawy wobec imigrantów jako grupy osób mogą podlegać generalizacji w odniesieniu do zgromadzonych doświadczeń i przechowywanych w pamięci doznanych emocji. Ich przedmiotem mogą być relacje z wybraną grupą osób, które funkcjonują już jakiś czas poza krajem i aby dalej wykonywać swoją pracę zawodową, zmuszone były zaadaptować się do obowiązującej w Europie kultury obyczajowej, zaakceptować normy wzajemnego bytowania, a są uogólniane na wszystkich imigrantów. Niezależnie jednak od tego, czy doświadczenie to jest przeniesione i uogólnione na grupę wszystkich osób pochodzących z określonego kręgu kulturowego, właśnie doświadczenie wydaje się ważnym czynnikiem zapobiegającym powstawaniu stereotypów i uprzedzeń). $Z$ tego względu bardziej pozytywne postawy mogą wynikać z pozytywnych doświadczeń, głownie odnoszących się do współpracy zawodowej, a w związku z tym z braku myślenia opartego na stereotypach [Bartkowiak 2016, s. 76]. Natomiast negatywne charakterystyki imigrantów, jeśli wykluczymy oceny oparte na myśleniu stereotypowym, podobnie jak pozytywne, mogą także być efektem doświadczeń wynikających z kontaktów z przedstawicielami odmiennej nacji i obserwacji prezentowanych przez nich skutecznych sposobów realizacji założonych celów i determinacji w dążeniu do ich osiągania. Wspomniana determinacja sprawia, że pomijają oni uznane za etyczne w naszym kręgu kulturowym wzorce zachowania. Podobne wnioski płynęły z badań, które przeprowadzili C.B. Fell, K.J. König i J. Kammerhoff [2016]: uznanie pewnych zachowań za etyczne czy pożądane wynikało z określonego doświadczenia, ukierunkowującego proces myślenia, postrzegania 
i wartościowania. Można oczekiwać, że nadmierna determinacja postrzegana jako pozytywna cecha imigrantów i przejaw przedsiębiorczości mogła przerodzić się w zachowanie przekraczające normy moralne i doprowadziła do podejmowania zachowań nieakceptowanych społecznie.

Na szczególną uwagę zasługuje różnicowanie postaw w zależności od kraju pochodzenia imigrantów. Zróżnicowanie to, a w szczególności postawy negatywne, w zależności od kraju pochodzenia i częstotliwości współpracy zawodowej z osobami z różnych kręgów kulturowych może wynikać z nagłaśniania przez media mających coraz częściej miejsce incydentów agresji i przejawów terroryzmu z negatywnymi bohaterami pochodzącymi z Afryki Północnej lub Azji Południowo-Wschodniej. Na podobne rezultaty badawcze powołuje się w swoim opracowaniu S. Przytuła [2014, s. 170-171], wskazując kraj pochodzenia jako determinantę stosunku pracowników do obcokrajowców. Uzyskane w wyniku badań opisanych w artykule dane to potwierdzają.

Rozważając możliwości przeciwdziałania negatywnym postawom wobec imigrantów, można stwierdzić, że skutecznym remedium (na co zwróciły uwagę osoby badane) wydaje się promowanie wiedzy o innych kręgach kulturowych, wprowadzanie i rozwijanie dobrych praktyk w zakresie budowania współpracy na poziomie relacji między dziećmi i młodzieżą w szkołach, jak i osób dorosłych na forum zawodowym.

Zaprezentowane badania nie są wolne od ograniczeń. Należy do nich niezbyt liczna próba badawcza, która sprawia, że rezultaty badawcze i wnioski należy traktować z dużą ostrożnością, nie dokonując ich generalizacji. Ponadto specyfika próby badawczej sprawia, że należy je odnieść do grupy wykształconych przedstawicieli pokolenia Y, które nie jest reprezentatywne dla osób posiadających wyższe wykształcenie.

Kolejny czynnik wynika z metody badawczej, która miała charakter badania sondażowego (wyłączywszy pytania projekcyjne), obarczonej dążeniem osoby badanej do zaprezentowania się z jak najkorzystniejszej strony.

Niezależnie od ograniczé́ przeprowadzone badania zdaniem autorek stanowią wkład w empiryczną dokumentację postaw Polaków wobec imigrantów.

\section{Literatura}

Aiken R.L. [1978], Late Life, Philadelphia Press, Philadelphia.

Bartkowiak G. [1988], Niepetnosprawni w przemysłowych zakładach pracy, Instytut Wydawniczy Związków Zawodowych, Warszawa.

Bartkowiak G. [2016], Zatrudnianie pracowników wiedzy 65 plus. Perspektywa pracowników i organizacji, Wydawnictwo Adam Marszałek, Akademia Finansów i Biznesu, Warszawa-Toruń. 
Bennet M.J. [1993], Towards Ethnorelativism: A Developmental Model of Intercultural Sensivity [w:] Education for the Intercultural Experience, ed. R.M. Paige, Intercultural Press, Yarmouth, Maine.

Cabańska J. [2015], Uwarunkowania migracji ludności na jednolitym rynku europejskim na przykładzie państw członkowskich Unii Europejskiej, Uniwersytet Ekonomiczny w Poznaniu, Poznań (niepublikowana praca doktorska).

Chiswick B.R., Cohen Y., Zach T. [1997], The Labor Market Status of Immigrants: Effects of the Unemployment Rate at Arrival and Duration of Residence, „Industrial and Labor Relations Review", vol. 50, nr 2, https://doi.org/10.1177/001979399705000206.

Chung-wen Ch. [2014], Does Job Position Moderate the Relationship between Gender and Ethics?: A Cross-cultural Analysis, „Cross Cultural Management: An International Journal", vol. 21, nr 4, https://doi.org/10.1108/ccm-01-2013-0018.

Dobrescu E.M. [2015], The Role of Italian Minority in the Economic Modernization of Romania, ,Journal of International Communication Research”, April-July.

Fell C.B., König K.J., Kammerhoff J. [2016], Cross-Cultural Differences in the Attitude toward Applicants' Faking in Job Interviews, ,Journal of Business and Psychology”, vol. 31, nr 1, https://doi.org/10.1007/s10869-015-9407-8.

Fiske S.T., Cuddy A.J.C., Glick P., Xu J. [2002], A Model of (Often Mixed) Stereotype Content: Competence and Warmth Respectively Follow from Perceived Status and Competition, ,,Journal of Personality and Social Psychology”, vol. 82, nr 6, https://doi. org/10.1037//0022-3514.82.6.878.

Garssen J., Nicolaas H. [2008], Fertility of Turkish and Moroccan Women in the Netherlands: Adjustment to Native Level within One Generation, „Demographic Research”, vol. 19, nr 33, https://doi.org/10.4054/demres.2008.19.33.

Hartgers M., Besjes G. [2014], Voortijdig schoolverlaters na zes jaar [w:] Jaar rapport Integratie 2014, eds R. van der Vliet, J. Ooijevaar, E. Wobma, Centraal Bureau voor de Statistiek, Den Haag/Heerlen.

Heath A.F., Rothon C., Kipli E. [2008], The Second Generation in Western Europe: Education, Unemployment, and Occupational Attainment, ,Annual Review of Sociology”, vol. 34, nr 1, https://doi.org/10.1146/annurev.soc.34.040507.134728.

Heckhausen J., Dixon R.A., Baltes P.B. [1989], Gains and Losses in Development throughout Adulthood as Perceived by Different Adult Age Groups, „Developmental Psychology", vol. 25, nr 1, https://doi.org/10.1037//0012-1649.25.1.109.

Hein J., Beger R.R. [2001], Legal Adaptation among Vietanmese Refugees in the United States: How International Migrants Litigate Civil Grievances during the Resettlement Process, „International Migration Review”, vol. 35, nr 2, https://doi. org/10.1111/j.1747-7379.2001.tb00024.x.

Hobcraft J., Kiernan K. [2001], Childhood Poverty, Early Motherhood and Adult Social Exclusion, „British Journal of Sociology”, vol. 52, nr 3, https://doi.org/10. 1080/00071310120071151.

Huschek D., Liefbroer A.C., Valk H.A.G. de [2010], Timing of First Union among Second-generation Turks in Europe: The Role of Parents, Peers and Institutional Context, „Demographic Research”, vol. 22, nr 16, https://doi.org/10.4054/demres.2010.22.16.

Immigrant Integration. The Dutch Case [2000], eds H. Vermeulen, R. Penninx, Het Spinhuis, Amsterdam. 
Kleinepier T., Valk H.A.G. de [2015], Ethnic Differences in Family Trajectories of Young Adult Women in the Netherlands: Timing and Sequencing of Events, ,Demographic Research", vol. 35, nr 24, https://doi.org/10.4054/demres.2016.35.24.

Koryś P., Okólski M. [2004], Czas globalnych migracji. Mobilność międzynarodowa w perspektywie globalizacji, Seria: Prace Migracyjne, nr 55, Instytut Studiów Społecznych, Uniwersytet Warszawski, Warszawa.

Lesthaeghe R. [2010], The Unfolding Story of the Second Demographic Transition, „Population and Development Review”, vol. 36, nr 2, https://doi.org/10.1111/j.17284457.2010.00328.x.

Majda A., Zalewska-Puchała J., Barczyk E. [2013], Postawy studentów pielęgniarstwa wobec osób odmiennych kulturowo, „Problemy Pielęgniarstwa”, t. 21, nr 3.

Marek A., Skowron-Nalborczyk A. [2005], Nie bój się islamu. Leksykon dla dziennikarzy, Więź, Warszawa.

Migrants in Europe: A Statistical Portrait of the First and Second Generation [2011], Eurostat, Luxembourg.

Nowicka E. [2011], Blaski i cienie migracji. Problemy cudzoziemców w Polsce, Wydawnictwo Uniwersytetu Warszawskiego, Warszawa.

Przytuła S. [2014], Międzynarodowa kadra menedżerska, Wydawnictwo Uniwersytetu Ekonomicznego we Wrocławiu, Wrocław.

Psychologia konsumenta [2014], red. K. Stasiuk, D. Maison, Wydawnictwo Naukowe PWN, Warszawa.

Ron P. [2007], Elderly People's Attitudes and Perceptions of Aging and Old Age: The Role of Cognitive Dissonance?, ,International Journal of Geriatric Psychiatry”, vol. 22, nr 7, https://doi.org/10.1002/gps.1726.

Rosencrantz H., McNewin T.E. [1969], Factor Analysis of Attitudes toward the Aged, „Gerontologist”, vol. 9, nr 1, https://doi.org/10.1093/geront/9.1.55.

Sanders J.M., Nee V. [1996], Immigrant Self-Employment: The Family as Social Capital and the Value of Human Capital, ,American Sociological Review”, vol. 61, nr 2, https://doi.org/10.2307/2096333.

Smolin J. [2011], Burning the Past. Moroccan Cinema of Illegal Immigration, „South Central Review", vol. 28, nr 1, https://doi.org/10.1353/scr.2011.0011.

Soros G. [2002], George Soros on Globalization, Perseus Book, Cambridge.

Stefaniak A., Bilewicz M., Winiewski M. [2015], Uprzedzenia w Polsce, Stowarzyszenie Filomatów, Liberi Libri, Warszawa.

Stefaniak A., Witkowska M. [2015], Społeczne kontakty Polaków, czyli czy znamy ludzi innych niż my sami i czy chcemy ich poznawać [w:] Uprzedzenia w Polsce, red. A. Stefaniak, M. Winiewski, M. Bilewicz, Liberi Libri, Warszawa.

Stephan W.G., Stephan C.W. [1985], Intergroup Anxiety, ,Journal of Social Issues”, vol. 41, nr 3, https://doi.org/10.1111/j.1540-4560.1985.tb01134.x.

Strabac Z., Listhaung O. [2008], Anti-Muslim Prejudice in Europe. A Multilevel Analysis of Survey Data from 30 Countries, ,Social Science Research”, vol. 37, nr 1, https://doi. org/10.1016/j.ssresearch.2007.02.004.

Windzio M. [2011], Linked Life-events: Leaving Parental Home in Turkish Immigrant and Native Families in Germany [w:] A Life-course Perspective on Migration and Integration, eds. M. Wingens et al., Springer, Hamburg.

Wzory i autorytety Polaków [2009], www.CBOS.pl (data dostępu: 20.06.2016). 
Zomeren M. Van, Fischer A.H., Spears R. [2007], Testing the Limits of Tolerance: How Intergroup Anxiety Amplifiles Negative and Offensive Responses to Out-group-initiated Contact, „Personality and Social Psychology Bulletin”, vol. 33, nr 12, https://doi. org/10.1177/0146167207307485.

Zorlu A., Mulder C.H. [2011], Ethnic Differences in Leaving Home: Timing and Pathways, ,Demography”, vol. 48, nr 1, https://doi.org/10.1007/s13524-010-0012-1.

\section{Attitudes of Poles with Higher Education towards Immigrants in the Context of Professional Cooperation}

(Abstract)

The article discusses the attitudes of Poles with higher education to immigrants. The theoretical part examines attitudes (categorized as either declared or actual) towards immigrants of selected individual nations, as well as their level of adaptability to the culture and customs of the host country. The empirical part presents the results of the research.

The article seeks answers to the following questions: what are the attitudes of educated Poles towards immigrants and working with them on the professional forum? are the attitudes contingent on the nationality/country of origin?

76 individuals responded to a questionnaire developed for the study. The research reveals differences in attitudes towards immigrants within the criteria used for their evaluation and their relationship as well as the nation of origin.

Keywords: attitude towards immigrants, country of origin, professional cooperation, representatives of other cultures. 